\title{
Rok 17 i jego jubileusze
}

W roku 2017 obchodzimy 150. rocznicę urodzin Józefa Klemensa Piłsudskiego. Jest to popularna, powszechnienie ceniona, ale też kontrowersyjna postać w historii Polski, dlatego zasługuje na ciągłe studiowanie. Ze względu na rocznicowe obchody poświęcono J. Piłsudskiemu dużo miejsca w mass mediach, dlatego w felietonie skupię się na innych, nie tak często przywoływanych wydarzeniach, będących jubileuszami roku 17.

Rok 1917 (przed stu laty) to przemiany rewolucyjne w Rosji. W lutym wybuchła rewolucja lutowa, która rozpoczęła się od strajku w Zakładach Putiłowskich w Petersburgu, którego nazwę zmieniono na Piotrogród. Strajk rozpoczął się 18 lutego starego stylu, 3 marca nowego, i szybko rozszerzył się z hasłami „Precz z caratem”, „Precz z wojną”, „Chleba”. Niezadowolenie ogarnęło żołnierzy w Piotrogradzie, część wojska przeszła na stronę zrewolucjonizowaną. Wybuchły powstania w stolicy i w Moskwie oraz innych miastach. Car Mikołaj II abdykował 15 marca na rzecz brata Michała, ale ten zrezygnował z tronu następnego dnia. Tak więc carat upadł 16 marca 1917 roku po trzystu latach panowania w Rosji - od 1613 roku i obioru cara Michała. Nastąpiła nowa epoka w Rosji, walka o władzę między Komitetem Tymczasowym Dumy Państwowej pod kierownictwem M. W. Rodzianki a radami komitetów robotniczych i żołnierskich, które zaczęły się organizować, gdyż były jeszcze nieprzygotowane do walki i przejęcia władzy. Czas ten nazwano dwuwładzą. Bolszewicy pod władzą Lenina rzucili hasło „Cała władza w ręce rad” i zaczęto przygotowywać zbrojne przejęcie władzy w drodze przewrotu. Zorganizowano oddziały zbrojne Czerwonej Gwardii i rozszerzano udział przedstawicieli bolszewików w radach robotniczych, chłopskich i żołnierskich. Porozumiano się z marynarzami Floty Bałtyckiej i przygotowano demonstracje, które Rząd Tymczasowy spacyfikował w lipcu 1917 
roku. Bolszewicy podgrzewali wrzenie rewolucyjne w zakładach pracy, na wsi, w wojsku i flocie. Powołano Komitet Wojskowo-Rewolucyjny przy Radzie Piotrogrodzkiej. W jego skład, jako kierownictwo, wchodzili też członkowie Wojenno-Rewolucyjnego Ośrodka KC SDPRR(b) w składzie A. S. Bubnow, F. Dzierżyński, M. Swierdłow, J. W. Stalin, M. Urycki. Jego pracami kierował Lenin, a podobne komitety powstawały $\mathrm{w}$ innych miastach i na froncie, gdzie dysponowały oddziałami zbrojnymi i stanowiły realną siłę. Rozbudowywano Czerwoną Gwardię. Lenin z terenu Finlandii przybył do Piotrogradu i zgłosił potrzebę przygotowania zbrojnego powstania, co KC SDPRR(b) przyjął prawie jednogłośnie (swoje sprzeciwy zgłosili L. Kamieniew, G. Zinowjew, których po paru latach będzie zwalczał Stalin). Termin powstania wyznaczono na 7 listopada (25 października starego stylu, stąd nazwa rewolucja październikowa). Już 6 listopada bojówki rewolucyjne obsadziły mosty, dworce, elektrownie, banki, pocztę i telegraf, inne instytucje państwowe. Ogłoszono odezwę do obywateli Rosji o obaleniu Rządu Tymczasowego i zgłoszono przejęcie władzy przez Komitet Wojskowo-Rewolucyjny. Zażądano kapitulacji od Rządu Tymczasowego, a wobec oporu zorganizowano szturm na jego siedzibę w Pałacu Zimowym. Szturm poprzedził słynny wystrzał z „Aurory” - krążownika, który zacumował na Newie.

W momencie wybuchu powstania Gwardia Czerwona liczyła około 40 tysięcy osób, w innych miastach gotowych do działań było ponad 200 tysięcy, zrewolucjonizowane oddziały wojska liczyły około 150 tysięcy żołnierzy zwolenników przejęcia władzy, a marynarzy z Floty Bałtyckiej zaagitowano około 80 tysięcy. Liczby zwolenników nowej władzy i powstania stale rosły i walki zbrojne pojawiały się w nowych miastach oraz okręgach. Po przejęciu władzy w Piotrogrodzie walki objęły Moskwę i inne miasta. Do końca grudnia większość terytorium Rosji podporządkowano nowej władzy. Obradujący w Piotrogrodzie II Zjazd Rad powołał nowy rząd: Radę Komisarzy Ludowych z Leninem jako przewodniczącym, i ogłosił dekrety o pokoju i o ziemi. Wybrał także Ogólnorosyjski Centralny Komitet Wykonawczy Rad. Władza Rad (z rosyjskiego Sowietow) rozpoczęła okres bolszewickiej dyktatury w Rosji, która przejęła tradycje i tereny podległe carskiemu imperium.

Rewolucja przyczyniła się do upadku caratu i uwolnienia z zaborów ziem Polski, Litwy, Łotwy, Estonii i Finlandii. Rozpoczął się okres interwencji zbrojnych i walk wewnętrznych. Na wniosek Swierdłowa zamordowano rodzinę cara Mikołaja II. Po Leninie władzę w Rosji, jako Związku Radzieckim, przejął Stalin i wprowadził władzę totalitarną - kult jednostki.

W roku rewolucyjnych przemian w Rosji miały miejsce objawienia Matki Boskiej w Fatimie. Troje pastuszków, Łucja, Hiacynta i Franciszek, dozna- 
ło objawień i spotkało się z Matką Bożą sześć razy od 13 maja 1917 roku. Matka Boża przekazała trzy tajemnice, z których ostatnia jest jeszcze nie w pełni rozpoznana, ale zapowiada ważne i niezwykłe wydarzenia. Jednym z nich miał być zamach na papieża, a to się ziściło, ale Ojciec Święty został uchroniony przed śmiertelnym strzałem i po intensywnym leczeniu wrócił do swoich prac i obowiązków, chociaż widoczne było Jego osłabienie i wyraźne starzenie się. $Z$ objawieniami fatimskimi łączy się trzynaście znaków stwierdzonych jako cudy oraz cud wirującego słońca, który widzieli wszyscy tłumnie zgromadzeni 15 października 1917 roku.

Jan Paweł II odbył trzy pielgrzymki do Fatimy i wyjętą ze swojego ciała kulę zamachowca umieścił w Koronie Matki Bożej jako dziękczynienie za opiekę i ratunek. Fatima należy do najbardziej znanych sanktuariów, stale rozwija swą działalność i rozbudowuje. W 2017 uroczyście obchodzono stulecie objawien. Dawne źródełko stało się podstawą leczniczych zabiegów, po których odnotowuje się kolejne uzdrowienia. W jednym z objawień Matka Boża wyraziła niepokój o losy Rosji, w której przygotowywano zamach, przejęcie władzy i niszczenie religii oraz wiary ludzi pracy. Nastały porządki totalitarne i dyktatura.

Rok 1517 jest początkiem reformacji religijnej w Europie i rokiem Marcina Lutra, który już wcześniej ogłaszał krytyczne poglądy wobec życia zakonnego, odrzucał średniowieczną interpretację Biblii. Piętnował odpusty i pokutę, a postulował konieczność łaski. W 1517 roku, 31 października, ogłosił 95 tez w Wittenberdze, przesłał je biskupowi Magdeburga i Moguncji, jako papieskiemu komisarzowi odpustowemu, i do swojego prowincjała, a także przybił tekst na drzwiach kościoła. W 1518 roku, 25 kwietnia, odbyła się dysputa teologiczna w Heidelbergu dla odparcia tez Lutra, który sformułował podstawy swojej teologii krzyża. Odbywały się dalsze spotkania i dysputy. Lutra popierało wielu nowych zwolenników: F. Melanchton, U. von Hutten, F. Siskingen. Popierali go także świeccy książęta rzeszy, bo odpowiadały im jego nauki o usamodzielnieniu się władzy od cesarza i papieża. Od dysputy w Ratyzbonie w 1541 roku wyodrębnił się kościół luterański jako ewangelicko-augsburski. Zasady tej odmiany chrześcijaństwa zyskały zwolenników nie tylko w Niemczech, ale także w Skandynawii i państwach nordyckich. Dotarły także do Polski nie tylko jako luteranizm, ale także kalwinizm, husytyzm czy arianizm, którego zwolenników zwano także Braćmi Polskimi. Reformacja religijna obchodzi swoje pięćsetlecie i wskazywane są jej wartości, zasługi oraz osiągnięcia także w kulturze, sztuce, obyczajowości i wychowaniu. 
Częstochowa jest starą miejscowością, notowaną w dokumentach z 1220 roku. Pochodzenie nazwy jest dzierżawcze od Częstocha, imienia znanego z Bulli gnieźnieńskiej. W etymologii ludowej wywodzi się tę nazwę od częstego chowania, gdyż miejscowość otoczona jest wzgórzami, które zasłaniają miejsce i kościół. Jasna Góra to największe w okolicy wzgórze wapienne o wysokości 296 m n.p.m. i od dawna był tam kościółek pod wezwaniem Najświętszej Marii Panny Dziewicy Wspomożycielki. W 1382 roku sprowadził na to miejsce paulinów książę Władysław Opolczyk. W dwa lata później przekazał mnichom pod opiekę obraz Matki Bożej, zwanej od tego miejsca Jasnogórską lub Częstochowską. Tradycja głosi, że jest to dzieło malarskie św. Łukasza Ewangelisty, który wykonał je w Jerozolimie w domu rodziców Marii na desce stołowej techniką tempery na płótnie na zaprawie klejowo-kredowej. Jeżeli legenda jest prawdziwa, to portret Maryi odtwarza z natury oblicze Matki Jezusa, malowany był w Jej domu i na materiale związanym z rodziną. Są to wartości relikwii i przyczyniły się do rozwinięcia kultu tego obrazu w Polsce i krajach ościennych. Najstarszy opis dziejów obrazu jest z 1474 roku i przekazuje historię pozyskania go przez cesarza Konstantyna Wielkiego, a z czasem dokonano przekazania tej ikony księciu Rusi Lwu. Jako kolejny zdobył go Opolczyk i przywiózł do Częstochowy. Obraz Matki Bożej otoczony został kultem i zyskał szybko sławę. Już w 1393 roku król Władysław Jagiełło potwierdził fundację Jasnej Góry i uposażył dodatkowo klasztor, a w 1430 roku zapewnił przeprowadzenie rekonstrukcji obrazu po napadzie, rozboju i profanacji. Jadwiga i Jagiełło spowodowali przebudowę kaplicy drewnianej na kamienną w stylu gotyckim, co obecnie stanowi prezbiterium świątyni rozbudowywanej w kolejnych etapach. Powstał od XV wieku kościół o trzech nawach, rozbudowano klasztor i kwatery dla wojska, bo powstała twierdza z załogą ponad 150 żołnierzy, obwarowana wysokimi murami, które ochraniały klasztor w czasie najazdu Szwedów w 1655 roku oraz innych oblężeń, łącznie z konfederatami barskimi. Obecny stan murów i bastionów został obniżony na polecenie cara Aleksandra po wojnach z Napoleonem. Klasztor niszczyły także pożary, a wieża była pięciokrotnie odbudowywana i obecnie liczy 106 metrów i jest najwyższą wieżą kościelną w Polsce.

W roku 1717, co nas szczególnie obchodzi, jako wydarzenie sprzed trzystu laty, papież Klemens XI zezwolił na koronację świętego obrazu koronami papieskimi. Była to pierwsza taka uroczystości ma ziemiach polskich, ale w 1909 korony papieskie zostały zrabowane. Odnowił je Pius X w 1910 roku. 
Jasna Góra stała się nie tylko miejscem szczególnego kultu, ale także wydarzeń narodowych. Tu odbyły się słynne śluby króla Jana Kazimierza w czasie potopu szwedzkiego i ich 300. rocznica 26 sierpnia 1955 roku, przygotowana przez prymasa Stefana Wyszyńskiego. Obchodzono uroczystości Tysiąclecia Chrztu Polski 3 maja 1966 roku. Odwiedzał Jasną Górę Jan Paweł II. W 1982 roku zorganizowano uroczysty jubileusz 600-lecia sprowadzenia obrazu.

Częstym uczestnikiem uroczystości jasnogórskich i pielgrzymek był kardynał Stefan Wyszyński, który ze swym poprzednikiem, prymasem $\mathrm{Au}$ gustem Hlondem, przyjął założenie, że „jeżeli przyjdzie wyzwolenie to za sprawą Maryi” i sam mawiał: „Wszystko postawiłem na Maryję” i stał się Jej niewolnikiem jeszcze w więzieniu w Stoczku.

W 2017 roku uroczyście obchodzono 300-lecie koron papieskich z 1717 roku nadanych przez papieża Klemensa XI. Dzisiaj Maria Jasnogórska ma koron więcej, bo od kardynała Wyszyńskiego, bursztynową i perłową oraz słynną różę Pawła VI, upominki Jana Pawła II i liczne wota składane w podzięce przez wiernych.

Na Jasnej Górze inicjował prymas Wyszyński Rok Wielkiej Nowenny Tysiąclecia Chrztu Polski, odnowił Akt Oddania narodu polskiego w macierzyńską niewolę Maryi, zorganizował wieloletnie nawiedzania parafii przez kopię cudownego obrazu Matki Bożej Częstochowskiej.

Rok 17 to także rocznica zgonu Tadeusza Kościuszki, który zmarł w Solurze 15 października 1817 roku w wieku 71 lat, co nie było jeszcze wiekiem zbyt podeszłym, ale dały o sobie znać rany odniesione pod Maciejowicami oraz panująca w okolicach Solury choroba zwana febrą nerwową.

Zwłoki Naczelnika sprowadzono do kraju, a car Aleksander wyraził zgodę na ich złożenie w nekropolii królewskiej na Wawelu. Pogrzeb odbył się 22 czerwca 1818 roku i był wielką manifestacją patriotyczną. Kościuszko spoczął obok grobowców Jana III Sobieskiego i księcia Józefa Poniatowskiego. Serce Kościuszki przekazano do Muzeum Polskiego w Rapperswilu, a obecnie znajduje się w Zamku Królewskim w Warszawie.

Uroczystości pogrzebowe, a następnie kolejne rocznice wydarzeń bojowych w Polsce i Stanach Zjednoczonych skupiały liczne tłumy i owocowały cennymi pamiątkami. Odsłoniono tablice, nadawano imię Naczelnika ulicom i placom, wznoszono pomniki, zostawał patronem szkół, sypano dla uczczenia jego pamięci kopce, z których najbardziej znany jest ten z Krakowa. W stulecie śmierci upamiętniono Kościuszkę na ziemiach polskich w ponad stu miejscowościach, odsłonięto 37 tablic i 27 pomników. Do najbardziej znanych i cenionych należą pomniki na Wawelu, w Łodzi i Poznaniu. 
Wiele z nich zniszczyli Niemcy w czasie ostatniej wojny i okupacji. Część odbudowano, pojawiły się nowe. Nadal brak jednak Muzeum Tadeusza Kościuszki i jego pamięć jest kultywowana w małych izbach pamięci: w Maciejowicach, a właściwe Podzamczu, w Koryznówce i Wiśniczu oraz na polu bitwy pod Racławicami. Swoistym pomnikiem jest Panorama Racławicka we Wrocławiu przeniesiona ze Lwowa i ochroniona przed zniszczeniem. Za granicą, zwłaszcza w Stanach, upamiętniają Kościuszkę pomniki, zwłaszcza w Waszyngtonie w parku Lafayette i w Akademii Wojskowej w West Point.

Tadeusz Kościuszko był wybitnym wojskowym, specjalistą inżynierii i budowy obronnych umocnień. Był także politykiem o demokratycznych poglądach. Planował uwolnienie Murzynów w swoich dobrach nadanych mu przez Kongres Stanów Zjednoczonych oraz w dziedzicznym majątku na Litwie, ale do realizacji tych planów nie doszło. Był uznanym rycerzem wolności i demokracji, otrzymał honorowe obywatelstwo Francji i wcześniej Stanów Zjednoczonych wraz z awansem na generała armii amerykańskiej.

Jego postać budziła uznanie i szacunek u takich współczesnych jak Thomas Jefferson, William Henry Harrison, cenił go także Napoleon, a po kongresie wiedeńskim także car Aleksander I chciał pozyskać jego życzliwość jako przyszły król Królestwa Polskiego podporządkowanego Rosji. Pamiętać trzeba, że car Paweł I uwolnił z niewoli Kościuszkę oraz kilkuset polskich oficerów - jeńców z powstania.

W nauczaniu historii, a także literatury, imię Kościuszki wnosi wiele wartości wychowawczych i etycznych, a bohater epopei narodowej na cześć Naczelnika otrzymał imię utrwalone w tytule Pana Tadeusza. Kościuszko interesował się także nauczaniem i planowanie edukacji, utrzymywał kontakty z Janem Henrykiem Pestalozzim. Spotykał się z nim i korespondował. Studiował też jego prace, a po latach, gdy przebywał w Solurze odwiedził zakład wychowawczy Pestalozziego, zapoznając się z formami kształcenia i urządzeniami szkoły. Prowadził wnikliwe rozmowy z nauczycielami i uczniami zakładu w Yverdun. Zwiedzał także inne szkoły w Szwajcarii, zwłaszcza kształcące młodzież wiejską do zawodów potrzebnych w rolnictwie i gospodarce oraz życiu na wsi. W piśmie do Adama Jerzego Czartoryskiego postulował organizowanie szkół rzemieślniczych w małych miastach dla dzieci włościan i mieszczan. Proponował, by wysyłać do Szwajcarii na naukę i obserwację przyszłych organizatorów i kierowników szkół polskich, co zapewni przeniesienie dobrych wzorów i doświadczeń szwajcarskich do Polski. Zdawał sobie sprawę, że Polski już nie ma, ale liczył, że zdoła się odbudować. Do Jeffersona, prezydenta Stanów, pisał w odpowiedzi na stałe zaproszenie 
do emigracji: „jestem jedynym prawdziwym Polakiem w Europie, wszystkich innych okoliczności uczyniły poddanymi różnych mocarstw".

Dwusetna rocznica zgonu Tadeusza Kościuszki powinna mobilizować do poznania i popularyzowania jego życiorysu oraz dokonań wojskowych i postawy obywatelskiej, bo należy On do wybitnych synów naszej Ojczyzny, co poświadczył czynami i gorącymi myślami o jej odbudowę i pomyślność.

Rok 17 w historii dynastii Jagiellonów ma szczególną wartość. W roku 1387, czyli 630 lat temu, Władysław Jagiełło był już koronowanym królem Polski oraz księciem Litwy, którą chrystianizował wraz z żoną królową Jadwigą Andegaweńską, która za pontyfikatu Jana Pawła II została wyniesiona na ołtarze. W 1417 roku Jagiełło żeni się po raz trzeci z Elżbietą z Pilczy Granowską i było to dokładnie 600 lat temu. To małżeństwo budziło różne kontrowersje, ale król był bardzo szczęśliwy w tym związku. W dziesięć lat później, w 1427 roku, urodził się Jagielle syn Kazimierz, który po dwudziestu latach został królem Polski po zgonie starszego brata, zwanego Warneńczykiem. Kazimierz IV Jagiellończyk należał do władców najdłużej panujących w naszym kraju, a także był ojcem czterech królów, świętego i kardynała. Ojciec Kazimierza urodził się jako poganin i został ochrzczony w 1386 roku już będąc w pełni dorosłym władcą Wielkiej Litwy. Kazimierzowi urodziło się sześciu synów, a 500 lat temu, w 1467 roku - Zygmunt, król Polski od 1507 roku, z czasem zwany Zygmuntem Starym (jego panowanie trwało 41 lat i jest określane złotym wiekiem kultury polskiej). Niestety syn jego, Zygmunt August, przeżył ojca o 24 lata i zmarł bezpotomnie w 1572 roku, dokonawszy w 1569 wielkiego dzieła, jakim była unia polsko-litewska zawarta w Lublinie.

Nagrody Nobla są przyznawane od 1901 roku, a sto lat temu w 1917 otrzymali je: z fizyki Charles Glover Barkla, z literatury Karl Gjellerup duński poeta, dramaturg i powieściopisarz, który po dwu latach zmarł, oraz także Duńczyk - pisarz i felietonista Henrik Pontoppidan opisujący życie biednych warstw ludności chłopskiej. Obaj laureaci należą dzisiaj do zapomnianych autorów, ale przed stu laty byli laureatami jeszcze w okresie trwającej wojny. Czas wojenny sprzyjał natomiast nagrodzeniu Noblem Międzynarodowego Komitetu Czerwonego Krzyża za pomoc poszkodowanym w wyniku wszelkich konfliktów zbrojnych i pomoc humanitarną ofiarom wojny i przemocy. Już w pierwszej edycji Nagród Nobla z 1901 roku laureatem został Henri Dunant - twórca całej organizacji Czerwonego Krzyża, ale w czasie wojny uznano wartość działalności Międzynarodowego Komitetu Czerwonego Krzyża. Innych nagród nie przyznano. Podobnie tylko część nagród przyznano w roku następnym i dopiero po zakończeniu wojny Pokojo- 
wą Nagrodę Nobla przyznano (w 1919 roku) 28. prezydentowi Stanów Zjednoczonych Tomasowi Woodrowowi Wilsonowi.

Pięćdziesiąt lat temu, w 1967 roku, Nagrody Nobla otrzymali: w dziedzinie fizyki Hans Albrecht Bethe - amerykański fizyk pochodzenia niemieckiego za prace poświęcone mechanizmom produkcji energii w gwiazdach; a w dziedzinie chemii wyróżniono trzech uczonych: Manfreda Eigena wraz z R. G. Wreyfordem Norrishem i Georgem Porterem za badania nad bardzo szybkimi reakcjami chemicznymi powodowanymi zakłóceniami równowagi za pomocą bardzo krótkich impulsów energii; w dziedzinie fizjologii i medycyny nagrodę otrzymali: Ragnar A. Granit, Haldan Hartline i George Wald za odkrycie podstawowych procesów fizjologicznych i chemicznych zachodzących w mózgu i oku podczas widzenia. Nagrodę z literatury otrzymał gwatemalski pisarz, poeta, dziennikarz i dyplomata Miguel Angel Asturias za twórczość na temat obyczajów i tradycji Indian Ameryki Łacińskiej. Jego najbardziej znane dzieła to Legendy z Gwatemali, Ludzie z kukurydzy, Pan prezydent, Bananowa trylogia.

Tradycje Nagród Nobla zasługują na obszerniejszą informację. Alfred Nobel, Szwed żyjący w latach 1833-1896, był znanym przemysłowcem i naukowcem. Wynalazcą dynamitu, sztucznego jedwabiu, syntetycznej gumy i skóry. Zgłosił do rejestracji 355 patentów, zyskał sławę i majątek. W listopadzie 1895 roku sporządzi testament, w którym swój ogromny majątek zapisał na Fundację Nobla z nagrodami w sześciu naukach oraz w literaturze i działalności na rzecz pokoju. Po zgonie Nobla 10 lutego 1896 roku podjęto niełatwe zadanie przyznawania nagród. Utworzono 19 czerwca 1900 roku Fundację Nobla, a Szwedzka Akademia Nauk została dysponentem jego majątku i decydentem nagród. Przyznaje się je w czterech naukach: fizyce, chemii, fizjologii lub medycynie, ekonomii (od 1968 roku) oraz literaturze i za działalność na rzecz pokoju. Pierwsze nagrody wręczono 10 grudnia 1901 roku i jest to stały termin. Pierwsi laureaci to między innymi: Wilhelm Röntgen w fizyce, Emil von Behring w fizjologii za badania immunologiczne, Sully Prudhomme - poeta francuski w literaturze, Jean Henri Dunant - założyciel Czerwonego Krzyża otrzymał Pokojową Nagrodę Nobla.

Od 1901 do 2016 roku przyznano łącznie 886 nagród indywidualnym osobom i 26 instytucjom: w dziedzinie fizyki 203 osoby, z chemii 175, z fizjologii i medycyny 212, z literatury 113, nagrodę pokojową uzyskało 104 osoby i 26 instytucji, nagrodę z nauk ekonomicznych od 1969 wręczono 78 razy. Dwie nagrody z literatury nie zostały przyjęte: przez Borysa Pasternaka w 1958 roku i Jeana Paula Sartra w 1964. Jeszcze czterech laureatów nie odebrało nagrody z powodów politycznych lub zakazu władz niemieckich, wietnamskich czy chińskich. 
Dla nas ważny jest przede wszystkim udział Polaków w Nagrodach Nobla. Już w 1901 roku nominowany do tej nagrody był Henryk Sienkiewicz, co nastąpiło także w trzech latach następnych, i dopiero w 1905 roku autor Trylogii i Quo vadis otrzymał nagrodę. Wcześniej, bo w 1903 roku, otrzymała Nagrodę Nobla z fizyki Maria Curie-Skłodowska wraz z mężem Piotrem i Antonim Henrykiem Becquerelem. Maria była już w 1902 roku nominowana do tej nagrody, a w 1911 uzyskała ją z chemii i jest jedną z czterech uczonych nagrodzonych Noblem dwukrotnie. Henryk Sienkiewicz i Maria Skłodowska otrzymali nagrody jako obywatele: on - Rosji i ona - Francji, gdyż Polska odzyskała niepodległość dopiero w 1918 roku. Pierwszym naszym laureatem został w 1924 roku Władysław Reymont, nominowany już w 1919 roku. Kolejni polscy laureaci to Czesław Miłosz z literatury w 1980 roku, Lech Wałęsa w 1983 - nagroda pokojowa, i Wisława Szymborska w 1996 z literatury. Jest to ostatnia polska laureatka, czekamy na Nobla już ponad dwadzieścia lat.

Ważnym uzupełnieniem tej szóstki laureatów są znani i cenieni nominaci, którzy nie uzyskali nagrody, ale byli do niej zgłaszani. Niektórzy wielokrotnie, a najwcześniej Karol Olszewski w 1904 roku z fizyki i Eliza Orzeszkowa w 1905 z literatury. Wielokrotnie nominowano Ludwika Zamenhofa do pokojowej nagrody od 1907 roku.

Łącznie z laureatami nominowano 21 osób, w tej liczbie najczęściej zgłaszano pisarzy ze Stefanem Żeromskim, Marią Dąbrowską, Leopoldem Staffem, Jarosławem Iwaszkiewiczem, Janem Parandowskim, Tadeuszem Zielińskim i Witoldem Gombrowiczem na czele. Wśród nominowanych zgłoszono także marszałka Józefa Piłsudskiego do pokojowej nagrody w 1934 roku oraz Adama Rapackiego w 1966. Nominowano także polskich uczonych Ludwika Hirnwelda, Tadeusza Rechsteina, Wojciecha Świętosławskiego, Oskara Minkowskiego. Bogata jest także lista laureatów pochodzenia polskiego, którą otwiera Albert Michelson z fizyki w 1907, a są na niej także Isaac B. Singer z literatury w 1978 roku, Menachem Begin i Szimon Peres - laureaci pokojowej nagrody, Irena Joliot-Curie - córka Marii Skłodowskiej z nagrodą z chemii 1935 r. Ostatni na tej liście to Leonid Hurwicz laureat z ekonomii w 2007 roku, i Robert Lefkowitz z chemii w 2012 roku. Łącznie 24 laureatów to Polacy i przyznający się do polskiego pochodzenia cudzoziemcy, wśród nich prezydent i premier Izraela, a także prezydent Polski w latach 1990-1995, laureat pokojowej nagrody w 1983 roku. 